\title{
Rüsen's response to the crisis of historicism
}

\author{
Martin Wiklund \\ Pós-doutorando no Departamento de História das Ideias e Teoria da Ciência da Universidade de Göteborg, Suécia \\ martin.wiklund@idehist.gu.se
}

Como citar este artigo: Wiklund, Martin. "Rüsen's response to the crisis of historicism". Intelligere, Revista de História Intelectual, vol. 3, n², p. 90-104. 2017. Disponível em http://revistas.usp.br/revistaintelligere>. Acesso em $\mathrm{dd} / \mathrm{mm} / \mathrm{aaaa}$.

\begin{abstract}
Although Rüsen only discusses the crisis of historicism explicitly in his work occasionally, his general perspective on historical knowledge can be interpreted as a response to the crisis. Different responses to the crisis of historicism correspond to different interpretations of its main problems. In order to specify Rüsen's response, a number of aspects of his perspective are pointed out as solutions to such problems. Indirectly, the analysis discloses problems that any plausible attempt to come to terms with the crisis of historicism ought to handle. By identifying differences to other contemporary responses to the crisis of historicism, the continuing relevance of Rüsen's approach is demonstrated.
\end{abstract}

Keywords: Philosophy of History; Meaning; Instrumental rationality.

\section{Introduction}

The crisis of historicism has become a topic of interest among contemporary theorists like Frank Ankersmit and Herman Paul. As Paul has pointed out, Hayden White's perspective on history writing, which has been an important point of orientation for theoretical debates in recent decades, can be understood as a response to the crisis of historicism. ${ }^{1}$ Ankersmit has called for a return to historicism and its idea of the historical individual. ${ }^{2}$ White and Ankersmit theorists represent different responses to the crisis of historicism. Although Jörn Rüsen only addresses the crisis of historicism explicitly in a few of his texts, his general perspective on historical knowledge can to a large extent - this will be one of my claims - be interpreted as a response to the crisis of historicism. One of the central questions guiding this article is, consequently, in what sense can Rüsen's general theoretical perspective on historical thinking and historical research (Geschichtswissenschaft) be seen as a response to the crisis of historicism? A second central issue, oriented towards to the contemporary debate within theory of history, concerns the relevance of his response in relation to the perspectives mentioned above.

${ }^{1}$ Herman Paul, "Hayden White and the Crisis of Historicism". In Re-figuring Hayden White, eds. Frank Ankersmit, Ewa Dománska, Hans Kellner (Stanford: Stanford University Press 2009), 54-73.

${ }^{2}$ Frank Ankersmit, “The Necessity of historicism”, Journal of the Philosophy of History, 4 (2010), 226-240. 
The argument will be developed in several steps. Before anything else, it is necessary to explain why it is not such a crazy idea to discuss theoretical perspectives like Rüsen's, outlined after the 1960s, as responses to the crisis of historicism. Apart from deepening the understanding of important dimensions of Rüsen's perspective, such an analysis makes it possible to articulate problems relevant to take into account in the contemporary debate within theory of history. This also concerns the interpretation of the crisis of historicism. Since the concepts of historicism and the crisis of historicism are so confused, it is necessary to make some distinctions. I will then articulate a number of problems related to the crisis of historicism that Rüsen tried to solve, by analysing his dissertation on Droysen. Indicating his solutions to those problems makes it possible to indirectly draw some conclusions about the fundamental problems of the crisis of historicism. Finally, I return to the point of departure, the contemporary debate on the crisis of historicism within theory of history, and point at some significant differences to alternative responses to the crisis of historicism and the relevance of Rüsen's approach.

\section{The returning crisis of historicism}

If the crisis of historicism took place in the early twentieth century, how could Rüsen's perspective, developed from the 1960s and later, be interpreted as a response to that crisis? That is indeed a legitimate question. But, firstly, a certain form of 'Historismus' was the main current of historical thought during the early post-war era in West Germany. In the 1960s, it came under attack from Hans-Georg Gadamer's hermeneutics in Wabrheit und Methode (1960), from the anti-positivism of the Frankfurt School's Critical Theory, and from the social sciences with its often ahistorical, structural perspectives and strong claims of relevance for the present. With such a strong demand for modernization and rejection of tradition, history seemed to have lost its relevance, except as a counter-image to the present. In this situation, 'Historismus' was often pictured as empiricist positivism of facts narrowly academic and focused on the past, and under attack for its lack of relevance for the present and for society, for action and orientation. Moreover, 'Historismus' was criticized for being uncritical, as opposed to the critical perspectives of Marxism and the Frankfurt School.

Secondly, the 1960s was a time of strong belief in rationality and planning in Germany as well as in many other Western countries. From the perspective of the form of rationality of the social sciences, history seemed to have little to offer for the rational orientation of action. 'Historismus' could in this context be criticized for the teleological tendencies of its history writing, that had accompanied the development of German society towards National Socialism and that partly explained the political irrationalism in Germany. ${ }^{3}$

Thirdly, it is possible to abstract, as Herman Paul does, the general problems related to the crisis of historicism, for example the contradiction between absolute moral values and historical contextualization of values, and identify similar crises of historicism in other periods than 1900-1930. Thus, Paul claims that Hayden White's Metahistory from 1973 can reasonably be interpreted as a response to the crisis of historicism. Actually, the relationship to the crisis of historicism of the early 20th century is more intimate than merely a similarity of problems. There are also historical links between White's sources of inspiration, such as Max Weber's philosophy of values and Sartrean existentialism, and the crisis of historicism after 1900: both Weber's and Sartre's perspectives can be seen as responses to what they perceived as shortcomings of historicism. ${ }^{4}$ Moreover, Friedrich Nietzsche, whose critique of historicism was of fundamental importance for the crisis of historicism, was an important source of inspiration for Weber and Sartre, and later also for White. The reappearance of Weberian and Nietzschean

${ }^{3}$ Karl Popper, The Poverty of Historicism (Routledge, 1957)

${ }^{4}$ Herman. Paul, "Hayden White and the Crisis of Historicism", in Re-figuring Hayden White, eds. Frank Ankersmit, Ewa Dománska, Hans Kellner (Stanford: Stanford University Press, 2009), 54-73. 
perspectives in historiography and theory of history in the decades after 1970 have indirectly made the crisis of historicism around 1900 an important point of orientation for contemporary theoretical reflection.

For such reasons, it is not just a wild, capricious idea to talk of responses to the crisis of historicism formulated in the 1960s. In a text on Meinecke from 1981 Rüsen actually mentions the similarities between the debate on historicism in the 1970s and the problems discussed in the debate in the 1920 s. ${ }^{5}$

Before we return to Rüsen's way of coming to terms with the crisis of historicism and how the perspective of a historian from the latter half of the 19th century could provide a solution in the 1960 s to the crisis of historicism of the 1920 s, it is necessary to make some distinctions between different concepts of historicism and the crisis of historicism.

\section{The concept of historicism and the interpretation of its problems}

The crisis of historicism has been defined and interpreted in a number of different ways. An additional difficulty is that the concept of 'historicism' or 'Historismus' is also frustratingly ambiguous. The concept of 'historicism' or 'Historismus' has often been used by its critics as a kind of 'Other', defining it in terms of the aspects they were critical of, i.e. historical relativism, fact-oriented positivism, narrow political history based on individual agents' actions and intentions, idealist history legitimizing the established regime and the state. Part of the reason why the definition of the crisis, of what it was about, is controversial is that it often defines the problems involved. Different responses to the crisis of historicism correspond to different interpretations of the crisis and its main problems.

Wittkau has argued that the problem of value relativism stood at the centre of the crisis, but that the understanding of the problems of the crisis of historicism was blurred by the influence of Friedrich Meinecke's interpretation and rehabilitation of early historicism. ${ }^{6}$ Paul argues, against Wittkau but with inspiration from Friedrich Jaeger, that the crisis of historicism did not so much concern the validity of values as such, but the ability of historicism to justify values, ideas of progress and religious belief. Using the distinction between 'classical historicism', represented by Ranke, and 'crisis historicism', referring to the kind of historicism that was dominant around 1900, Paul argues, in the footsteps of Friedrich Meinecke, that classical historicism had not produced or suffered from the kind of relativism that Wittkau focuses on, but had been able to justify values. When the underpinnings of classical historicism had lost its reliability, historicism entered a crisis as a form of justification of values and was then replaced for example by non-historical forms of justification. Whereas classical historicism had provided historical grounds for trust in divine providence and future progress, experiences around 1900, especially World War I, caused that trust to implode. Paul also mentions the theoretical difficulty created by the ontological distinction between 'is' and 'ought' in 'crisis historicism'.

There were more problems involved in the German debate around the crisis of historicism in the 1920s, than those that Paul emphasises, but these distinctions will suffice for the moment. In this text, the 'crisis of historicism' usually refers to the critique and debate about historicism around the 1920s in Germany, if nothing else is mentioned.

\footnotetext{
${ }^{5}$ Jörn Rüsen, ”Die Krise des Historismus in unzeitgemäßer Erneuerung - Friedrich Meineckes »Entstehung des Historismus«". In J. Rüsen, Konfigurationen des Historismus (Frankfurt am Main: Suhrkamp, 1993), 331-356. Cit. fr. 334.

${ }^{6}$ Annette Wittkau, Historismus. Zur Geschichte des Begriffs und des Problems (Göttingen: Vandenhoeck \& Ruprecht, 1992).

${ }^{7}$ Herman Paul, "A Collapse of Trust: Reconceptualizing the Crisis of Historicism", Journal of the Philosophy of History, 2 (2008), 63-82.
} 
Understanding more about the problems involved in the crisis of historicism, develops our understanding of different responses. Correspondingly, understanding more about different responses, deepens our understanding of the problems. Rather than stipulating what the problems involved in the crisis of historicism actually were and only then look at Rüsen's response, it is more productive to interpret Rüsen's response reciprocally in relation to the interpretation of the problems of the crisis of historicism. In that way, understanding Rüsen's response can disclose important problems to handle and deepen our theoretical Problembewußtsein of what it means to overcome the crisis of historicism.

\section{Recycling Droysen's historicism through Hegelian dialectics}

Rüsen turned to Droysen's theory of history in order to come to terms with the problems of historicism, Droysen being the most theoretical of the German historicist historians. Rüsen actually refers to several of the central texts of the classical crisis of historicism in the introduction to his dissertation on Johann Gustav Droysen from 1966 (published in 1969). How come? Rüsen's study on Droysen starts with an exposition of the general purpose of the investigation. The first issue that is mentioned is not, as might be expected, the definition of historicism or the need for critical Gesellschaftsgeschichte, but the relationship between philosophy and history, between philosophy of history and historical research (Geschichtswissenschaft). How come?

Despite the success of 'Historismus' in the sense that every possible aspect of the human world had been described in a historical perspective and made into an object for historical research, the self-understanding of the present seemed to have suffered a certain loss of history, as if the thoughts and actions of contemporary society were cut off from its historical development. In short, history did not seem to have any significance in the mind of contemporary society.

Die historische Methode steckt in dem Dilemma, daß sie um der «Objektivität» historischer Erkenntnis willen Geschichte zum Gegenstand historischer Forschung verdinglicht und damit die Entaktualisierung der Geschichte innerhalb des Modus ihrer Erforschung bestätigt. ${ }^{8}$

If historical knowledge is to have any significance for the self-understanding of people in the present, it cannot discard its practical relevance. And then the explanation for the centrality of the issue of philosophy and history appears:

Es [Historisches Denken] muß auf der Vermittlung von methodisch vergegenständlichter und aktuell geschehender Geschichte insistieren, nur leistet die Methode der Forschung allein diese Vermittlung nicht. Um ihretwillen muß Geschichtswissenschaft sich einer geschichtsphilosophischen Theorie öffnen. Die vorliegende Arbeit versucht zu einer solchen Verbindung von Geschichtswissenschaft und Geschichtsphilosophie durch eine Interpretation Droysens in der Aufhellung der Genese seiner Geschichtstheorie beizutragen. ${ }^{?}$

\footnotetext{
${ }^{8}$ Jörn Rüsen, Begriffene Geschichte. Genesis und Begrïndung der Geschicbtstheorie J. G. Droysens (Paderborn: Ferdinand Schöningh, 1969), 10.

${ }^{9}$ Ibid, $10 f$.
} 
Why turn to Droysen? What was Rüsen expecting to find there? Droysen was the most theoretically articulate of the historicist historians of the latter half of the 19th century and a methodically conscious historian. At the same time he was critical of, on the one hand, philology that idealized antiquity, especially classical Greece, for aesthetic and pedagogical purposes, and, on the other, historical scholarship based on critical methods and aiming merely at the empirical truth of the past but with no particular significance for the present. Thus, the two alternatives 'historical reality without significance' and 'ideal but unreal significance for the present' seemed to negate each other. Droysen greeted historical research and the use of critical empirical methods, but looked for a dialectical solution to the contradiction mentioned (between a meaningful but idealized image of the past and a real but meaningless past) in the 'real historical significance of historical phenomena'. To see the real historical significance of events and changes it was necessary to put the past, for example classical Athens, into a larger coherence of significance. ${ }^{10}$ In order to expose the meaning of the past in relation to the present, the past had to be mediated (vermittelt) ${ }^{11}$ with the present through this larger coherence.

The significance of the past for the present would become visible if the historian used the present as a point of departure and the past could be shown to incarnate the preconditions and principles of the present, so that the goal and direction underlying the direction of development in the present would become discernable in the past. ${ }^{12}$

In Droysen's historical thought, Christian ideas have a significant place. Rüsen analyses some of them through Droysen's history writing on Hellenism. Classical Athens represented the break with a mythical and religious world view, creating a straight opposition between rationality and tradition. Droysen reinterpreted the Hellenistic period after classical Greece and the advent of Christianity as a solution to the alienation and ethical disintegration of the polis in that era. Inspired by Hegel, Droysen uses the idea of reconciliation (Versöhnung) in Christianity as a basic principle for the dialectical form of history: life - death - resurrection; tradition negation - reconciliation; myth - abstract rationality - concrete and substantial rationality. ${ }^{13}$

Man was supposed to be reconciled with historical development by participating in the development of the world and making become reality. Instead of religion as subjective meaning and freedom from a meaningless world, or freedom as a negation of religion in favour of this world, religion was on the way to become reality in this world in terms of freedom and the ideals of practical reason.

Droysen diagnosed his own time as a time of crisis, a time of diremption (Entrweinng) and alienation (Entfremdung). This crisis was the result of the attempt to realize the abstract and ahistorical ideas of rationality and freedom related to the Enlightenment. It had produced a romantic reaction, reaffirming tradition and the past regardless of any demands of rationality. In that way, both the ahistorical rationality of the Enlightenment and the non-rational past of the romantic reaction confirmed the contradiction between history and reason. The existing world appeared as irrational, producing estrangement to society. The attempt to realize the ideals of freedom in an ahistorical way had resulted in unfreedom and a perverted form of freedom during the phase of the 'terror regime' of the French Revolution. The negation of religion and tradition had destroyed the existing Sittlichkeit, the living ethical traditions, with the result of alienation.

Droysen's solution to this was to think of rationality and freedom in a historical way, making it possible to bistorically reconcile Sollen and Sein, reason and history. Instead of negating

\footnotetext{
10 Ibid, $52 \mathrm{f}$.

${ }^{11}$ The word is based on the Hegelian concept of Vermittlung.

${ }^{12} \mathrm{~J}$. Rüsen, Begriffene Geschichte, 43-45.

13 Ibid, 55.
} 
reality from the heights of abstract rationality, the historical rationality of the existing society ought to be reconstructed, with a vision towards further realization of reason. Tradition and history were to be reconciled or mediated by reason. But the content of reason thereby had to be thought of in a historical manner, which means it has to transcend the ahistorical understanding of rationality of the Enlightenment to historical reason ('gescbichtliche Vernunft). A future dimension was opened in the dialectical history of the realization of reason. The ahistorical understanding of rationality belonging to the Enlightenment was merely a historical phase in that history. ${ }^{14}$

In a similar way, the past and the present was mediated and integrated in a larger historical coherence of the realization of freedom, so that the present was not merely negated, but historicized as a phase in the history of freedom. Instead of abstract and ahistorical freedom, freedom was given a concrete historical form, as part of a larger development of freedom. Freedom was interpreted as the principle of modernity ('Nenzeit), with the Reformation and the French Revolution as its decisive events. Underlying the development of modern society was thus a tendency towards freedom and consciousness of freedom. The state was within this paradigm interpreted not as the opposite of freedom that needed to be abolished, but as part of the concrete realization of freedom. The content of practical reason ought to become reality and the history of the present could be interpreted as characterized by such an underlying tendency, although with dialectical moments of negations and severe criticism. In Droysen's own words:

Denn allein eine wahrhaft historische Ansicht der Gegenwart, ihrer Aufgabe, ihrer Mittel, ihrer Schranken wird imstande sein, die traurige Zerrüttung unserer staatlichen und sozialen Verhältnisse auszuheilen und die rechten Wege zu einer froheren Zukunft anzubahnen. ${ }^{15}$

Droysen's reconstruction of the history of the present had the function of understanding and articulating the fundamental tendencies of the present in a historical context, from a point of view relevant to the present and its questions and problems. Thus historical knowledge in his perspective did not merely have a contemplative character, something that 19th century historicism has often been accused of. In Droysen's case, the search for historical knowledge was consciously inspired by an explicit practical intention on the theoretical level. ${ }^{16}$ Historical knowledge could clarify the present about its historical conditions and orient it with regard to the deeper, underlying tendencies towards the concrete realization of the principles of practical reason. ${ }^{17}$

This should not be understood as mere presentism. Droysen's historicism was based on Humboldt's idea of a transcendental subject of interpretation whose categories of interpretation correspond to the historical forces that have shaped the present. Subject and object should not be understood as isolated, but as mediated. Along the same line, the object of cognition should not be understood merely as a dead thing.

In drastischer Polemik gegen eine Geschichtswissenschaft, die sich mit der Erforschung methodisch verdinglichter Vergangenheit bescheidet, betont Droysen die Aufgabe der Geschichtswisssenschaft in der Bildung des Zeitalters zum geschichtlichen Bewußtsein seiner selbst. ${ }^{18}$

\footnotetext{
14 Ibid, $71 \mathrm{ff}$.

${ }^{15}$ Johann Gustav Droysen, Historik. Vorlesungen über Ensyklopädie und Methodologie der Geschichte, ed. R. Hübner, 4th ed. (Darmstadt, 1960), 383; here quoted from J. Rüsen, Begriffene Geschichte, 60.

${ }^{16}$ J. Rüsen, Begriffene Geschichte, 120-122, 159.

${ }^{17}$ Ibid, 158.

${ }^{18}$ Ibid, 93. Italics in Rüsen's original text. The italics should not be interpreted as representing a quotation from Droysen, since quotations in Rüsen's text are indicated by quotation marks.
} 
Droysen überträgt nicht einfach ungeschichtlich politische Denkmodelle aus dem Kampf der Gegenwart auf die wehrlose Vergangenheit. Er versucht mit diesen Analogien, am geschictlichen Beispiel, Gegenwart jenseits der falschen Perspektive ihrer unmittelbaren Gegebenheit selbst zu erhellen. Umgekehrt wird erst Vergangenheit in ihrer Bedeutung erkennbar, wenn sie auf die Gegenwart als Voraussetzung historischer Hermeneutik bezogen wird. [...] erst die mit dem Ernst aktueller Geschichtserfahrung gestellte Frage an die Vergangenheit ordnet diese in einen Sinnzusammenhang ein, in der Gegenwart und Vergangenheit historisch vermittelt sind. ${ }^{19}$

The experiences and problems of the present made historical questions and categories of interpretation relevant, so that historical phenomena would become significant for the present. But the present was not understood as a fixed point of departure determining the interpretation of the past, since the understanding of the present was also informed by the interpretation of the history of the present. The mediation ('Vermittlung') between past and present was part of the groundwork of Droysen's theory of history and historical reason.

Presentism uses a yardstick independent of the past for interpretation and evaluation. Such an approach would correspond to the ahistorical rationalism of the Enlightenment that sets ahistorical rationality against the irrational past. ${ }^{20}$ The idea of Droysen's historical reason was that the form and content of reason must be historically grounded. That presupposes a more dialectical relation to the past than presentism or the kind of past-oriented philology that focuses on historical facts but cuts off the relation to the present.

According to Droysen's perspective on historical reason, intellectual principles and directions such as the Enlightenment and Romanticism could be interpreted as relative rational moments with their relative historical justification in a larger historical perspective of reason. The future direction of development would not be decided by some invented yardstick of reason, but developed historically in the present through a dialectical reconciliation of the opposed historical moments of reason, which implies a reformulation of the yardstick. The false alternatives of revolutionary and anti-revolutionary realization of freedom ought to be reconciled by mediating both alternatives as justified moments of a concept of the whole that represented its immanent reason and its historical possibility of success. ${ }^{21}$

As opposed to both abstract philosophy of history and history writing focused on mere facts, Rüsen drew attention to Droysen's integration of a philosophical dimension into historical research: 'er philosophierte sozusagen mit den Tatsachen der Geschichte, um sie bedeutsam werden zu lassen. ${ }^{22}$ This philosophical dimension should not be understood as merely speculative. Its task was rather to perceive and formulate the general principles or tendencies of history from the manifold of historical phenomena, as well as to interpret historical events and processes in relation to such general ideas. ${ }^{23}$

Theorie ist dann zur leitenden Sinnbestimmung praktischer Veränderung geworden und die Gegenwart aus der Pathologie einander ausschließender Prinzipien, aus der «schlechten Dialektik», in der die Geschichte der Freiheit zur Geschichte der Unfreiheit pervertiert,

\footnotetext{
${ }^{19} \mathrm{Ibid}, 45$.

${ }^{20} \mathrm{Ibid}, 70 \mathrm{f}$.

${ }^{21} \mathrm{Ibid}, 93,112$.

22 Ibid, 49.

${ }^{23} \mathrm{Ibid}, 61$. See also p. $157 \mathrm{f}$.
} 
hinausgeführt zur Verwirklichung der Freiheit als einzig sinnvoller Zukunft der Geschichte. ${ }^{24}$

This means that the philosophical dimension of historical knowledge was constituted by what Droysen and Rüsen call 'historical thinking', rather than by an independent theory or a fixed philosophy of history. It concerned both theoretical and practical reason and the realization of the freedom and ethical potential of mankind: 'Erst in der Teilhabe am realen Prozeß der sittlichen Mächte erfüllt der historisch verstehenden seine geschichtliche Aufgabe.'25

Consequently, the meaning of historical phenomena did not belong merely to a subjective dimension and the past as such was not understood as void of meaning, but must be seen in relation to the intellectual (geistige) 'middle' of history and the 'sittliche Mächte' as the centre of this process.

Geschichte wäre dann weder zu einem bloßen Dingzusammenhang rational vergegenständlicht noch zur reinen Innerlichkeit subjektiver Weltanschauung in ästhetischem Sinne verflüchtigt: sie stünde als aktueller Prozeß menschlicher Selbstverwirklichung zur Tradition (Übersetzung) nach Maßgabe menschlicher Vernunft an, und historische Theorie wäre dann ihrer praktischen Dimension versichert. ${ }^{26}$

The substance of history, 'the History over all histories', had an immanent teleological dimension, related to the 'sittliche Mächte'. ${ }^{27}$ The meaning of historical events and turning points depended on their relation to these ethical powers and the realization of freedom and the ideals of practical reason. The meaning of the present was interpreted correspondingly and disclosed with regard to its place in that process. That does not mean, however, that the telos of the process was given. As earlier explained, the direction and goal of development was formulated as a result of historical thinking and as a dialectical solution to contemporary contradictions and oppositions between conflicting tendencies. Historical thinking thus did not merely receive norms and goals from elsewhere, but formulated goals and directions for the future, based on the past and the historically motivated dimension of the present as well as conflicts and crises in the present. Practical reason had become historical. In Droysen's own words that Rüsen quotes: "das, was ist, aus dem, was war, und ward, zu deuten, nachzuweisen, wie unserer Gegenwart die lebendige Fortbildung einer an Resultaten reichen Zeit ist, ja wie sie eben dorther ihre Rechtfertigung, ihre Richtung, und, wo Gott will, ihre Zukunft hat". ${ }^{28}$

Before we go any further, let me briefly summarize the issues mentioned above the problems that Rüsen's re-interpretation of Droysen's theory of history was supposed to solve. First, historical knowledge and historical research was not understood as based on a contemplative and aesthetic attitude, or a merely cognitive or theoretical interest, but was basically grounded in a practical interest. Second, as opposed to ahistorical rationality and historical development without rationality, Droysen formulated a perspective of historical reason. Third, as opposed to the past as unrelated and therefore insignificant to the present, the past and the present were mediated, so that the past as the history of the present could be shown to be significant to the present. Fourth, as opposed to the idea of a fundamental split between the interpretative subject and the object, the object of historical understanding was at the same

\footnotetext{
${ }^{24}$ Ibid, 93.

25 Ibid, 122.

${ }^{26}$ Ibid, 122. See also p. 123.

${ }^{27}$ Ibid, 127.

${ }^{28}$ Johann Gustav Droysen, "Rede zur tausendjährigen Gedächtnisfeier des Vertrages zu Verdun” (1843), in Deutsche Akademiereden, ed. F. Strich (München, 1924), 89-110. Here quoted from J. Rüsen, Begriffene Geschichte, 94.
} 
time dependent on the present and the categories of interpretation of the subject and constitutive of that subject. Fifth, the role of normativity and the political dimension in historical thinking that had been eclipsed in some other versions of historicism. Sixth, in order for historical studies to be able to accomplish its interpretative tasks, a philosophical dimension must be integrated in historical research. Philosophical dimension such as a teleological dimension and a larger coherence of significance were merged dialectically with historical scholarship based on critical research methods. From such a perspective, it becomes possible to understand the deeper meaning of Droysen's expression 'forschend zu verstehen' (understanding through research).

\section{Addressing the crisis of historicism in the 1960s}

How could the perspective of a historian from the latter half of the 19th century provide a solution in the 1960 s to the crisis of historicism of the 1920s? As I have already hinted earlier, some clues can be found in the introduction to the study on Droysen. There Rüsen writes that since the victory of historicism, all spheres of human life had been made available for historical perspectives, but that the self-understanding of the present at the same time was threatened by a kind of 'loss of history', as if history were of no relevance to the present. History did not appear any longer as a meaningful dimension of the present, but rather appeared as an independent force with no particular meaning or rationality. In this context, Rüsen refers to Ernst Troeltsch's and Karl Heussi's writings on the crisis of historicism as if they were part of the theoretical and historiographical present of the 1960s. ${ }^{29}$

An important issue was the practical relevance of historical research and knowledge. That made it necessary to overcome the limitations of historical methods that objectified the past and thereby cut off the meaning of the past from the present. Dimensions of philosophy of history needed to be integrated in historical research. These aspects in Droysen's thought made him relevant to the problems in the 1960 s, according to Rüsen, but that made it necessary to re-interpret Droysen.

Rüsen's re-interpretation of Droysen was a way of coming to terms with the crisis of historicism. On several occasions in the book, Rüsen defends Droysen and his relevance against other interpreters of Droysen and historicism, interpreters that formulated their approaches in relation to the crisis of historicism. One such important interlocutor is Friedrich Meinecke. His interpretation of historicism in Die Entstehung des Historismus (1936) had been very influential and represented one response to the crisis of historicism. Meinecke had defended the early form of German historicism, formulated against the universalist rationalism of the Enlightenment. It was a form of historicism based on the idea of the development of the historical individual and its proper, internal telos and incommensurable yardstick. But, Rüsen points out, Meinecke's interpretation of historicism in general and of Droysen in particular was too one-sided. Whereas Meinecke emphasized the irrational character of history as opposed to the limitations of rationalist perspectives, Droysen had tried to avoid such conclusions by reconciling history and reason dialectically and by mediating the past with the present, as earlier explained. Droysen explicitly rejected the alleged opposition between Enlightenment and history, between historical development and rationality, as part of the crisis that Droysen had tried to solve. ${ }^{30}$ Moreover, if historicism according to Meinecke was based on the incommensurability of historical individuals, then Droysen must rather be understood as a critic of historicism. ${ }^{31}$ It should be observed that the idea of incommensurability is actually only one aspect of historicism, in some versions of historicism.

${ }^{29}$ J. Rüsen, Begriffene Geschichte, 10, n. 3.

${ }^{30}$ Ibid, 51, 68 n. 91-92.

${ }^{31}$ Ibid, $59 f$. 
Another significant interlocutor in this context is Gadamer, who had criticized historicism, including Droysen, in Wabrbeit und Methode (1960) for objectifying the past and for having a mere aesthetic, contemplative attitude to the objects of historical research. That had, according to Gadamer, had the destructive effects of cutting off the relation between historical interpretation and contemporary practice. ${ }^{32}$ But that is not true in Droysen's case. The dimension of practical reason is integrated in and inspires his theory of history in its foundations. ${ }^{33}$

\begin{abstract}
Erst in der Vermittlung mit Geschichte als lebendiger Gegenwart vermag die Subjektivität ihre hermeneutische Kraft zu entfalten und zu bewähren, die ihr in transzendentaler Selbstapperzeption innewohnt, und erst in dieser Vermittlung hat historische Hermeneutik ibren zugleich theoretischen und praktischen Sinn, hat sie ihre geschichtliche Vernunft. Geschichte wäre dann weder zu einem bloßen Dingzusammenhang rational vergegenständlicht noch zur reinen Innerlichkeit subjektiver Weltanschauung in ästhetischem Sinne verflüchtigt: sie stünde als aktueller Prozeß menschlicher Selbstverwirklichung zur Tradition (Übersetzung) nach Maßgabe menschlicher Vernunft an, und historische Theorie wäre dann ihrer praktischen Dimension versichert. ${ }^{34}$
\end{abstract}

In his book, Rüsen also mentions that the question of the relevance of historical research as well as its role in contemporary historical development, a question that Droysen dealt with explicitly, had more or less been absent for a long time, but that it recently had come to the fore in contemporary debate - in the 1960s. ${ }^{35}$

All of these problems - the incommensurability of historical individuals with its implications of historical relativism as opposed to rationalism, the aesthetic and contemplative or purely cognitive attitude of historicism, the objectification of the past and the lack of practical relevance of the past for the presence - were problems discussed in the crisis of historicism in the first half of the 20th century. Meinecke and Gadamer were important participants in the debate around historicism and developed their perspectives on historical studies in relation to the problems discussed in the crisis of historicism. Thus, Rüsen's reinterpretation and defence of Droysen's theory of history against Meinecke's and Gadamer's interpretations of historicism can be seen as an alternative way out of the crisis of historicism, but directed to the theoretical present in the 1960s. Droysen's critique of historical scholarship and abstract philosophy of history in his own time becomes a vehicle for Rüsen's critique of historical scholarship in post war Western Germany.

\title{
Rüsen's response
}

So far, we have concentrated our focus on Rüsen's book on Droysen. But what about Rüsen's own theory of history that he developed in the decades after his dissertation? To what an extent can his general perspective be understood as a response to the crisis of historicism? Around 1970 'Historismus' was criticized as the established form of historical scholarship by several significant theorists, such as Wolfgang Mommsen (Die Geschichtswissenschaft jenseits des Historismus, 1971) and Georg Iggers (The German Conception of History. The National Tradition of

\footnotetext{
32 Gadamer's model of dialogical interpretation and application and his idea of hermeneutics as practical philosophy can be understood as a response to that problem.

${ }^{33}$ J. Rüsen, Begriffene Geschichte, 120-122, 149 n. 139.

${ }^{34}$ Ibid, 122. Italics in orig.

${ }^{35}$ Ibid, 52.
} 
Historical Thought from Herder to the Present, 1968). ${ }^{36}$ These books, as well as Gadamer's Wabrheit und Methode, were discussed critically by Rüsen in a number of tests later published in 1976 as Für eine erneuerte Historik. Studien zur Theorie der Geschichtswissenschaft. ${ }^{37}$

When Rüsen confronts this criticism, he places historicism in a larger historical perspective that reveals the historically conditioned character of paradigms of historical research. The tradition of historicism itself must be historicised, not in the sense of simply understanding it in its restricted past historical context, but in the sense of thinking about its justification and legitimacy in a historical manner. There are structural differences between post war Germany and the 19th century that motivate changes of the established historicist tradition. Also, there is criticism that ought to be taken into account, concerning the relationship between politics and historical research, the possibility of critique of tradition as ideology, the knowledge-constitutive human interest or the practical function of historical research and history writing, the historicist idea of the substance of 'history' as 'spirit' ('Geist'), agents and structures as factors of explanation, individualizing vs. general perspectives, and the role of theory in relation to empirical historical research. But, as we know, the tradition of historicism is not only criticized and negated by Rüsen, certain features are also rehabilitated. The historical perspective on historicism has the positive function of exposing forgotten problems and alternative solutions, and of expanding the resources of argumentation. Just like in Rüsen's study on Droysen, history becomes a way of overcoming the limitations of historicism and of confronting the limitations of present theoretical currents. Historicism is historicised as a paradigm in a larger historical perspective of successive paradigms with their deficiencies and possibilities. Such deficiencies and possibilities, limitations and alternative solutions produce an orienting argumentative force for the future. ${ }^{38}$

Let us recall that many of the problems discussed around 1970 were also discussed around 1920 in relation to that crisis of historicism: the practical function of history, objectivity vs. normativity, the need for sociological and structural perspectives, idealism vs. materialism, the relevance of critical perspectives as opposed to legitimising perspectives of progress, the role of philosophy of history in relation to empirical research, and the limitations of historical individualism. ${ }^{39}$

Since there are a number of problems involved, Rüsen's response to the crisis of historicism must be differentiated. In the following, I will indicate a number of aspects of Rüsen's perspective of historical knowledge that can be seen as a response to the crisis of historicism. Since Rüsen's general perspective is relatively well known and is explained in other texts, in this context I will limit myself to pointing out the relevant aspects, without much further explanation. His general perspective on historical research is, firstly, based on practical functions or knowledge-constitutive human interests of history: historical orientation and formation of identity. This means that historical knowledge is not understood as based on a contemplative and aesthetic attitude, or a merely cognitive interest. The cognitive dimension - 'theory' - is

\footnotetext{
36 Wolfgang Mommsen, Die Geschichtswissenschaft jenseits des Historismus (Düsseldorf: Droste, 1971); Georg Iggers, The German Conception of History. The National Tradition of Historical Thought from Herder to the Present (Wesleyan University Press, 1968); German transl.: Deutsche Geschichtswissenschaft. Eine Kritik der traditionellen Geschichtsauffassung von Herder bis zur Gegenwart (München: dtv, 1971).

${ }^{37}$ Jörn Rüsen, Für eine erneuerte Historik. Studien zur Theorie der Geschichtswissenschaft (Stuttgart-Bad Cannstatt: FroomannHolzboog, 1976).

38 Jörn Rüsen, "Einleitung", "Für eine erneuerte Historik - Vorüberlegungen zur Theorie der Geschichtswissenschaft". In J. Rüsen, Für eine erneuerte Historik, 11-16, 17-44.

${ }^{39}$ Ernst Troeltsch, Der Historismus und seine Probleme. Erstes Buch: Das logische Problem der Geschichtsphilosophie. Kritische Gesamtausgabe, Bd. 16 (1-2), ed. Friedrich Wilhelm Graf (Berlin/New York: De Gruyter 2008 [orig. 1922]); Mannheim, Karl, "Historismus", in Wissenssoziologie. Auswabl aus dem Werk (Neuwied: Luchterhand, 1970), 246-307. Orig. published in Archiv für Soztialwissenschaft und Sozialpolitike, 52 (1924) H.1, 1-60.
} 
related to praxis. ${ }^{40}$ Secondly, the theory of historical consciousness as constitutive of historical meaning makes it possible to overcome the idea of a fundamental split between the interpretative subject and the object. ${ }^{41}$ This makes it possible, thirdly, to mediate the past with the present in such a way as to make the past significant for the present, as opposed to an unrelated and therefore insignificant past. ${ }^{42}$ Fourth, against the kind of historicism that is criticised for being focused on objective facts and void of any dimension of 'meaning' of the past for the present, the category of meaning ('Sinn') is put at the centre of Rüsen's perspective. ${ }^{43}$ Fifth, the category of 'meaning' makes it possible to regain dimensions of philosophy of history that were often lost in the professionalization of historical scholarship, without returning to any dogmatic philosophy of history: a teleological dimension and a larger coherence of significance. Just like Droysen and Troeltsch, Rüsen wants to combine such philosophical dimensions with historical scholarship based on critical research methods. ${ }^{44}$ Sixth, the dimension of normativity, which is a necessary dimension of history with a practical function, is not separated from proper historical research or passively accepted, but integrated into an extended form of scientific rationality, that is supposed to make it possible to reconcile theoretical rationality and practical reason, resulting in ethics of historical thinking. ${ }^{45}$ Seventh, and finally, with inspiration from Hegel and Droysen, Rüsen tries to formulate a perspective of historical reason and justification, as opposed to ahistorical rationality and historical development without rationality. ${ }^{46}$

I hope that the reader is now able to see why Rüsen's perspective on historical thinking and historical research to a large extent can be seen as a response to the crisis of historicism, to the one around 1920 and the one in the 1960s and 1970s. But what is the relevance of that in relation to the contemporary debate in theory of history?

\section{Rüsen's response as orientation for the future?}

What does it mean to overcome the crisis of historicism? What kind of response to the crisis of historicism one finds more convincing, depends on how one understands the crisis and the problems involved. Understanding more about the problems involved develops our ability to judge the plausibility of different responses.

When Herman Paul explains in what sense Hayden White's approach to history and history writing can be seen as a response to the crisis of historicism, the core of the problem is summarized as follows: 'Why should one want to study the past, if there is no moral education to be gained from it?'. ${ }^{47}$ The problem with historicism and ordinary historical scholarship in general is seen by White to be that rational inquiry is separated from the 'irrational' dimensions of myth, imagination, dream or fiction that could create some moral or political meaning in history writing, as opposed to the chaos of meaningless historical facts. The problem of the lack of meaning is supposed to be solved by the meaning-creating order and coherence of larger narrative patterns. In that way, the problem of the distance between the past and the meaning for the present is overcome. The problem of the practical function of history is combined by White with an existentialist understanding of the fundamental freedom of and moral

\footnotetext{
${ }^{40}$ Jörn Rüsen, Historische Vernunft. Grundzüge einer Historik I: Die Grundlagen der Geschichtswissenschaft (Göttingen: Vandenhoeck \& Ruprecht, 1983), 24f, 47-58.

${ }^{41}$ Ibid, 58-64.

${ }^{42}$ Ibid, 53-58.

43 Jörn Rüsen, "Geschichte als Sinnproblem”. In Jörn Rüsen, Zerbrechende Zeit. Über den Sinn der Geschichte (Köln: Böhlau, 2001), 7-42.

${ }^{44}$ J. Rüsen, Historische Vernunft, 51, 55, 111; Jörn Rüsen, Historische Orientierung. Über die Arbeit des Geschichtsbewußtseins, sich in der Zeit zurechtzufinden (Köln: Böhlau, 1994), 157; J. Rüsen, "Geschichte als Sinnproblem".

${ }^{45}$ J. Rüsen, Historische Vernunft, 98-108, 116-136; Jörn Rüsen, Kultur macht Sinn. Orientierung zwischen Gestern und Morgen (Köln: Böhlau, 2006), 59.

${ }^{46}$ J. Rüsen, Historische Vernunft, 8, 16f; J. Rüsen, "Geschichte als Sinnproblem"; J. Rüsen, Historische Orientierung, 246258.

${ }^{47}$ H. Paul, "Hayden White and the Crisis of Historicism”. Cit. 58.
} 
responsibility for the meaning constructed and its underlying values. The latter part concerns the justification of the historian's vision of the past, the values this is based on and the meaning implied. The solution to the ironic mode that resulted in the crisis of historicism, is a Nietzschean and existentialist one: to be authentic to one's moral and aesthetic aspirations, to be a courageous moral agent writing monumental histories with the help of one's imagination and creativity. 48

Compared to White, Rüsen's solution does, firstly, not only concern meaning in historiography, but meaning in historical knowledge. White's solution makes history writing - or certain kinds of history writing - worthwhile and meaningful, but the value of historical research and knowledge is difficult to discern. Secondly, the dimension of reason or rationality, both in its theoretical and in its practical sense, has little if any relevance in White's solution. White's form of practical reason does not really have a historical character (even if there is a historical dimension to morality in the sense that one is morally responsible for one's vision of the past with its moral and existential implications for one's attitude to life). In Rüsen's response, the interpretations of the past in relation the present and the future ought to be examined with regard to the rational justification of its dimensions of experience, significance and meaning in order to further practical reason in terms of historical orientation and identity formation.

Frank Ankersmit has pointed to and defended a concept from the tradition of historicism, the concept of a 'historical individual'. The historical individual as explained by Ranke and Humboldt means that 'each historical thing' (nation, epoch, civilization etc.) is argued to possess a 'historical idea', an 'entelechy', so to say, wholly specific for itself and for itself alone'. ${ }^{49}$ When Ankersmit comments on the crisis of historicism, he interprets it as a problem of historical relativism of values. Dismissing Troeltsch as looking for 'absolute and timetranscendent moral and theological truths' and adding that such an idea is absurd, he claims that the crisis of historicism was actually irrelevant. Consequently, a certain interpretation of classical historicism seems to become the solution to the evaporated crisis of historicism. Ankersmit's solution resembles and seems to be generally inspired by Meinecke's re-interpretation of the classical historicism in Die Entstehung des Historismus, a book which in fact was a response to the crisis of historicism. Ankersmit translates the historicist notion of the historical individual to the condition of the linguistic turn. Thus, the historical ideas must be interpreted not as independently existing ideas in the past, but as something existing within narratives, in historiography: 'we must situate it [the historical idea] in the historian's language about the past'. ${ }^{50}$

About Ankersmit's response to the crisis of historicism there are is much to be said, but for the sake of brevity, I will focus on two essential issues here. Firstly, the dismissive interpretation of the crisis of historicism contributes in an unfortunate way to the forgetting of the plurality of serious problems involved. It is of course natural that Ankersmit does not formulate solutions to those unmentioned problems, but that does not diminish the narrowing of the Problembewußtsein. Secondly, it is not clear what problem the solution that Ankersmit presents is actually supposed to alleviate. Whether value relativism is a problem or not, or what kind of relativism is plausible, can be let aside for the moment. But what the practical functions of historical scholarship and historical thinking should be is hardly a question the can be dismissed so easily.

Ankersmit's general argument is oriented to defend the idea that the identity of something is its history, and that is supposed to make historical knowledge relevant. Does that solve the central problem of the practical function of historical interpretations? How does it affect

\footnotetext{
48 Ibid.

${ }^{49}$ F. Ankersmit, “The Necessity of historicism”. Cit. 235.

${ }^{50}$ F. Ankersmit, 2010, 237.
} 
the relevance of the past for the present? The historicist idea of historical individuals tends to make the past irrelevant for the present, since every historical individual has its own proper and internal yardstick. When the historical individual concerned is the present in a particular society and culture, then the genetic history of the present can admittedly deepen the understanding of the fundamental ideas and the proper yardstick of this historical individual. Meinecke's book on the emergence of historicism is an example of such a genetic history, providing orientation in the present in relation to historical scholarship and the crisis of historicism. Whether that is a recommendable way of giving orientation to the present, is not selfevident and something I will return to it. There is an obvious risk that this simply reinforces the inherited ideas and goals of direction in an uncritical way and that questions about orientation for the future are simply answered in terms of authenticity: 'this is who we are'. In any case, most aspects of the past and most historical individuals, such as ancient Egypt, the Thirty Years' War or the reign of Louis XIV, hardly belong to the present in the sense described (depending on how we conceive of the present, of course). The problem of practical relevance thus still needs to be handled.

What is the relation of Rüsen's response to this? Interestingly enough, he has in fact written an article on Meinecke's response to the crisis of historicism. He points out that Meinecke recognized the problem of the practical function of historical knowledge, but he is less convinced by Meinecke's solution. Meinecke opposed the rationalism and the generalizing explanations of Enlightenment to the irrationalism of Historismus. Instead he emphasised the need to recognise the deep, irrational layers of the human soul and of historical development in order to understand historical individual formations. Rüsen agrees with the limitations of ahistorical, generalizing rationalism and its inability to understand historical individuals, but points out critically that Meinecke's reactualization of Historismus neglects the claim to scholarship and rationality within Historismus and the aspect of methodology. He also neglects the dimension of ideas that link the forces of cultural formation in the past with the interests of orientation in the present. In that way, Historismus was able to contribute to the consensual formation of the collective will power in the present. In Meinecke's interpretation, a practically efficient relationship of the present to the past is characterised by admiration, awe, and amazement touching the whole soul of the interpreter and his or her audience in the present. Such an aesthetic approach to the past cannot make claims to contributing to the formation of rational, collective will in the present.

Seine [Meinecke's] Ästhetisierung der Geschichte sanktioniert eine Ohnmacht des erkennenden Subjekts vor dem Kampf der Interessen im gesellschaftlichen Leben der Gegenwart. Der Anspruch des klassischen Historismus auf praktische Vernunft, mit dem seine Geschichtsschribung als Medium der Konsensbildung über gesellschaftliche Interessen auftrat, ist preisgegeben. ${ }^{51}$

This points, according to Rüsen, to the need for the use of a) theoretical concepts to interpret and make distinctions not necessarily available in the past as opposed to the irrationality of Einfüblung based on awe and amazement, b) perspectives and models from the social sciences that are able to grasp the forces of cultural formation and the relationship between conscious intentions and other determining factors in order to overcome the lack of realism in Meinecke's aestheticist historicism, c) a model of practical reason that is able to handle political conflicts of interests and criteria of meaning for the interpretation of the past in the present. A new, actualized form of Historismus would have to incorporate 'die unbestreitbare lebensweltli-

51 Jörn Rüsen, ”Die Krise des Historismus in unzeitgemäßer Erneuerung - Friedrich Meineckes »Entstehung des Historismus«". In J. Rüsen, Konfigurationen des Historismus (Frankfurt am Main: Suhrkamp, 1993), 331-356. Cit. 351. 
che Erfahrung einer fundamentalen Interessengebundenheit intentionalen Handelns in historische Erkenntnis über den inneren Zusammenhang von Kultur, Gesellschaft, Wirtschaft und Politik'. ${ }^{52}$ At the same time, there is, Rüsen adds, also something to be learnt from Meinecke for social sciences and history based on models from the social sciences: the fundamental historicization of interpretative perspectives and the individuality of historical phenomena that make the specifically historical character of human action accessible.

What about the practical function? 'Womit kann die Geschichtswissenschaft heute begründen, daß die Erkenntnis der Zeitspezifik vergangenen menschlichen Handelns und Leidens zur Orientierung gegenwärtigen Handelns notwendig ist?’53 Rüsen rejects decisionist pluralism and a subjective choice of fundamental norms and criteria of meaning as irrational, and instead underlines that in order to overcome such irrationalism, it is necessary to conceptualize a perspective of rational reconstruction of the past for the orientation of life and action in the present with criteria of validity that at least make it theoretically possible of forming consensually plausible perspectives of coherence between the past and the present. Articulate use of theories and theoretical presuppositions is necessary, but more important are the general norms of rationality: criteria of rational argumentation for reaching a valid consensus. ${ }^{54}$

Compared to the dissertation on Droysen, such a response to the crisis of tends to diminish the dimension of the specifically historical form of reason, the specifically historical form of justification. Droysen's Hegelian concept of historical reason has since around 1980 been exchanged for Habermas's model of rational argumentation. The idea of a historically based reason does not disappear, seen for example when Rüsen discusses utopia and history, but the integration of Habermas' theory of discourse rationality, the use of models from the social sciences, and the treatment of conflicts over the meaning of the past in terms of articulate theories and general criteria of meaning and significance, runs the risk of diminishing the importance of meaningful historical experience as a base for justification and potential critique of criteria, theories and models in the present. In that way, it runs the risk of obscuring the idea of a specifically historical practical reason that inspired Rüsen's dissertation on Droysen. ${ }^{55}$

The point of exposing differences between Rüsen's and other contemporary theorists' ways of responding to the crisis of historicism is not only that is makes the relevance of Rüsen's approach more evident, but also that is shows the plurality of problems that contemporary theorists need to respond to if they want to come to terms with the crisis of historicism.

\footnotetext{
52 Ibid, 352.

${ }^{53}$ Ibid, 354

54 Ibid, 354-356.

${ }^{55} \mathrm{~J}$. Rüsen, Historische Vernunft, 16: ">Vernünftig` ist ein historisches Denken, das in der Form einer Argumentation vor sich geht". However, a richer understanding of the dimension of reason in relation to historical thinking is presented in J. Rüsen, "Geschichte als Sinnproblem".
} 